\title{
EFFICACY OF MONOSODIUM GLUTAMATE IN THE AUSTRALIAN BLOWFLY, LUCILIA CUPRINA WIEDMANN (DIPTERA : CALLIPHORIDAE)
}

\author{
M. Begum*, M. A. Kabir, H. R. Khan and M. F. Rahman \\ Department of Zoology, University of Dhaka, Dhaka-1000, Bangladesh
}

\begin{abstract}
Efficacy of monosodium glutamate (MSG) was studied in the Australian blowfly, Lucilia cuprina at six different doses, viz. 0.5, 1, 2, 3, 5 and $10 \mathrm{~g}$, and the results were compared with the control. The effects of MSG were observed on the mortality, width and histology of Malpighian tubules (MTs) of the fly. The highest (100\%) and lowest (16.67\%) mortalities of the flies were recorded at $10 \mathrm{~g}$ and $0.5 \mathrm{~g}$ doses, respectively. Average widths of the MTs of flies in treatment ( $5 \mathrm{~g}$ dose) and control were $48.62 \mu \mathrm{m}$ and $58.85 \mu \mathrm{m}$, respectively. Histological observations through the cross section of the MTs showed the constriction at $0.5 \mathrm{~g}$ and $5 \mathrm{~g}$ doses.

Key words: Lucilia cuprina, monosodium glutamate, mortality, Malpighian tubules, histology.
\end{abstract}

\section{INTRODUCTION}

Various environmental chemicals, industrial pollutants and food additives have been found to cause harmful effects in living being. Most food additives act either as preservatives or enhancer of palatability. One such food additive is monosodium glutamate (MSG). When MSG is added to food, it provides a flavoring function similar to the naturally occurring free glutamate: which differs from the four classic tastes of sweet, sour, salty and bitter. MSG is used as a food additive for a long time in India, China, Thailand, Vietnam and some other tropical countries including Bangladesh where it is generally known as testing salt. MSG, otherwise known as AJI-NO-MOTO is the sodium salt of glutamic acid. Glutamate is one of the most common amino acids found in nature and is the main component of many proteins and peptides of most tissues. It is white crystalline powder with molecular weight of 187.13. MSG contains $78 \%$ of glutamic acid, $22 \%$ of sodium and water. Glutamate is also produced in the body and plays an essential role in human metabolism. It is a major component of many protein-rich food products, such as meat, fish, milk and some vegetables (Anonymous 2003).

In 1968, the first published report of an adverse reaction to MSG appeared in the New England Journal of Medicine where it was reported to be neurotoxic (Schaumburg et al. 1969). Recently there are some evidences for novel function controlled by glutamate which was reported both in vertebrates and insects.

*Corresponding author: murshida1972@yahoo.com 
Not only is it controlled by the direct application of glutamate, but also by interfering with glutamate receptor. MSG caused histological changes (i.e., tissue constriction) in kidney of adult rat (Eweka 2007) and induced damage in liver and kidney (Ortiz et al. 2006). It had also effect on the brain, stomach and testis of rats (Om'iniabohs and Eoeka 2007, Eoeka 2007, 2008). After infusion of 0.02M glutamate, renal blood flow fell significantly in rabbits which might cause constriction of blood vessels as well as kidneys (Malpas et al. 1996). In case of insects glutamate interfere with the reproductive system via nervous system (Begum et al. 2004). It has been claimed that MSG has physiological effects in both vertebrates and invertebrates (Malpas et al. 1996, Flynn et al. 2002, Begum et al. 2004). Since MSG causes constriction of kidneys of adult rats, it was intended to investigate on insects.

The present study therefore aims to observe the efficacy of monosodium glutamate (MSG) in the Australian blowfly, Lucilia cuprina Wiedmann.

\section{MATERIAL AND METHODS}

Rearing of flies: The laboratory reared flies, Lucilia cuprina, was obtained from a stock culture which has been maintaining at the Institute of Food and Radiation Biology, Atomic Energy Research Establishment, Savar, Dhaka since 1987. These flies were reared in the laboratory of Entomology, Department of Zoology, University of Dhaka at $28 \pm 2{ }^{\circ} \mathrm{C}$ with a $12 \mathrm{~h}: 12 \mathrm{~h}$ light:dark photoregime. Adult stock was kept in rectangular rearing cages $(20.32 \mathrm{~cm} \times 30.48 \mathrm{~cm}$ $\times 20.32 \mathrm{~cm})$ made of wood frame being covered with mosquito net. Newly emerged flies were provided with bovine liver, sugar and water soaked cotton wools while the larvae were fed with only bovine liver as food substances. The 3-day old insects were used for experimental purposes.

Treatment with MSG: $0.5,1,2,3,5$ or $10 \mathrm{~g}$ of MSG were dissolved separately in one $\mathrm{ml}$ of distilled water each. Three day old 10 adult flies were transferred from the stock culture and released in the small rearing cages containing a small petri dish with MSG solution soaked with a wad of cotton wool and left for $12 \mathrm{hrs}$. A control was selected in which only distilled water soaked cotton wool was placed. Insects were dissected after $12 \mathrm{hrs}$ to observe the histology of Malpighian tubules. All experiments were replicated thrice.

Mortality: The doses and the experimental procedures were similar as mentioned above. except in this experiment $0-24 \mathrm{hrs}$ old adult flies were used. Mortalities at different doses were observed and recorded every $24 \mathrm{hrs}$ interval and were continued up to $72 \mathrm{hrs}$. All experiments were replicated thrice. Mortalities were corrected according to Abbott's correction formula (Abbott 1925). 
Dissection of flies: Prior to dissection, the flies were narcotized with chloroform. Dissection of the flies was performed on the wax wad in a petri dish $(90 \mathrm{~mm})$ with the help of fine forceps and pointed needles under a stereoscopic binocular microscope $(20 \times)$. The required organ system was cleaned up by flushing away the unwanted tissues with saline solution $(0.9 \%$ $\mathrm{NaCl}$. Then the dissected organ system was placed on a microscopic slide for anatomical study or transferred to a second container for histological preparations. The dissected parts of the MTs were stained with eosin before fixation.

Measurement of width of the MTs: The width of the MTs of both control and treated flies was measured with the aid of an ocularmeter and stage micrometer under a compound microscope at x 10 magnifications.

Histological procedure: The dissected organs were fixed in aquous Bouin's fluid and dehydrated by passing through different grades $(70,80,90$ and $100 \%$ ) of ethyl alcohol. Finally, the tissues were embedded in paraffin. Serial sections were cut at 4-6 $\mu \mathrm{m}$ and mounted in Canada balsam following the usual procedures of deparaffinization and dehydration. The sections were stained with Heidenhein's haematoxylene, mounted with a drop of DPX and a cover slip (Chowdhury and Rahman 2008). Photographs were taken by a Canon Power shot 165 digital camera of 7 megapixel.

Statistical Analysis: The widths of Malpighian tubules of control and treated flies were compared using Student's t-test by SPSS software, Version 8. The mortality of the fly at different doses was corrected following Abbott's formula (Abbott 1925).

\section{RESULTS AND DISCUSSION}

Mortality of adults: Mean number and percentage of the mortality at different doses $(0,0.5,1.0,2.0,3.0,5.0$ and $10 \mathrm{~g})$ of MSG at 72hrs exposure are presented in Table 1 . The highest (100\%) and the lowest (14.33\%) mortalities were recorded at dose $10 \mathrm{~g}$ and $0.5 \mathrm{~g}$, respectively. In control, mortality was $3.33 \%$. Differences of mortality among different doses were found to be significant $(\mathrm{p}<0.05)$. Results showed that mortality was dose-dependent, i.e. with the increase of doses mortality also increased.

Measurement of width of the MTs: In control, the mean width of the MTs was $58.85 \mu \mathrm{m}$ while in case of treatment $(5 \mathrm{~g})$ it was $48.62 \mu \mathrm{m}$ (Fig. 3). Results showed that MTs became significantly $(\mathrm{p}<0.05)$ constricted after administration of $5 \mathrm{~g}$ of MSG. This morphological observation was further verified by histological studies. 
Table 1. Mortalities of $L$. cuprina at different doses of MSG at $72 \mathrm{hrs}$ exposure.

\begin{tabular}{lcc}
\hline Doses $(\mathrm{g})$ & $\begin{array}{c}\text { Number of fly died } \\
(\text { Mean } \pm \mathrm{SD})^{*}\end{array}$ & $\begin{array}{c}\text { Mortality } \\
(\%)\end{array}$ \\
\hline 0.0 (Control) & $1.0 \pm 1.0^{\mathbf{a}}$ & 3.33 \\
0.5 & $5.3 \pm 0.57^{\mathbf{b}}$ & 14.33 \\
1.0 & $6.0 \pm 1.0^{\mathbf{b}}$ & 16.67 \\
2.0 & $13.0 \pm 1.73^{\mathbf{c}}$ & 40.00 \\
3.0 & $16.7 \pm 0.58^{\mathbf{d}}$ & 52.23 \\
5.0 & $24.0 \pm 1.0^{\mathbf{e}}$ & 76.67 \\
10.0 & $30.0 \pm 0.0^{\mathbf{f}}$ & 100 \\
\hline
\end{tabular}

Each data represents the mean of 3 replications $(n=30)$; Mortality figures corrected by Abbott's Formula; Means represented by the same letters in the column are not significantly different at $5 \%$ level.

Histological changes in MTs of L. cuprina: Morphologically the MTs are long, thin, blindly ending tubes arising from the gut near the junction of the mid gut and hind gut (Fig. 1). The histological appearance of the MTs of dipterans is very simple (Fig. 2A). In general, they have no muscles other than a series of circular and longitudinal muscles. The principal cell types in the wall of the tubules have the free margins of the cell produced into closely packed microvilli which form the so called honey comb border or brush border. Beneath the brush border and circular muscle, basement membrane is present (Chapman 1982, Chowdhury and Rahman 2008). During the present study the permanent slides of cross section of MTs at $5 \mathrm{~g}$ and $0.5 \mathrm{~g}$ dose of MSG showed constriction of the tubules (Fig. 2B, C) brush border being ruptured and circular muscle constricted. In control, no such constriction was observed. The circular muscle, brush border and basement membrane were found to be intact (Fig. 2A).

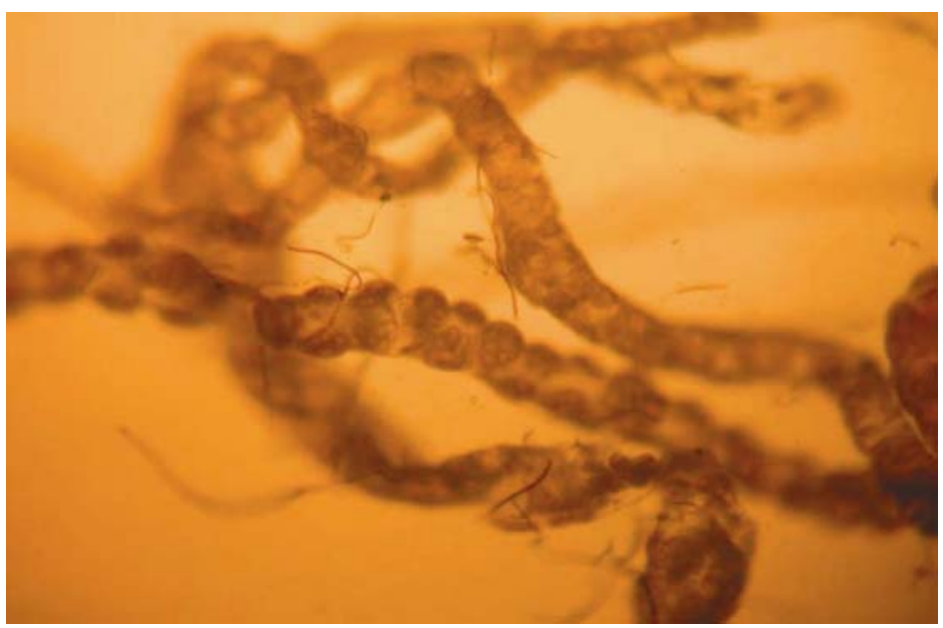

Fig. 1. The Malpighian tubules of Lucilia cuprina (x40) 
The present study dealt with the efficacy of MSG in the Australian blowfly, L. cuprina. Results demonstrated that the adult mortality was highest (100\%) in the highest dose of $10 \mathrm{~g}$ while the lowest mortality (14.33\%) was obtained at the dose of $0.5 \mathrm{~g}$. Mortality increased with the increasing doses of MSG. The dose $10 \mathrm{~g}$ was considered to be toxic because $100 \%$ mortality was obtained in this dose. Intake of any toxic material can cause death either by interference
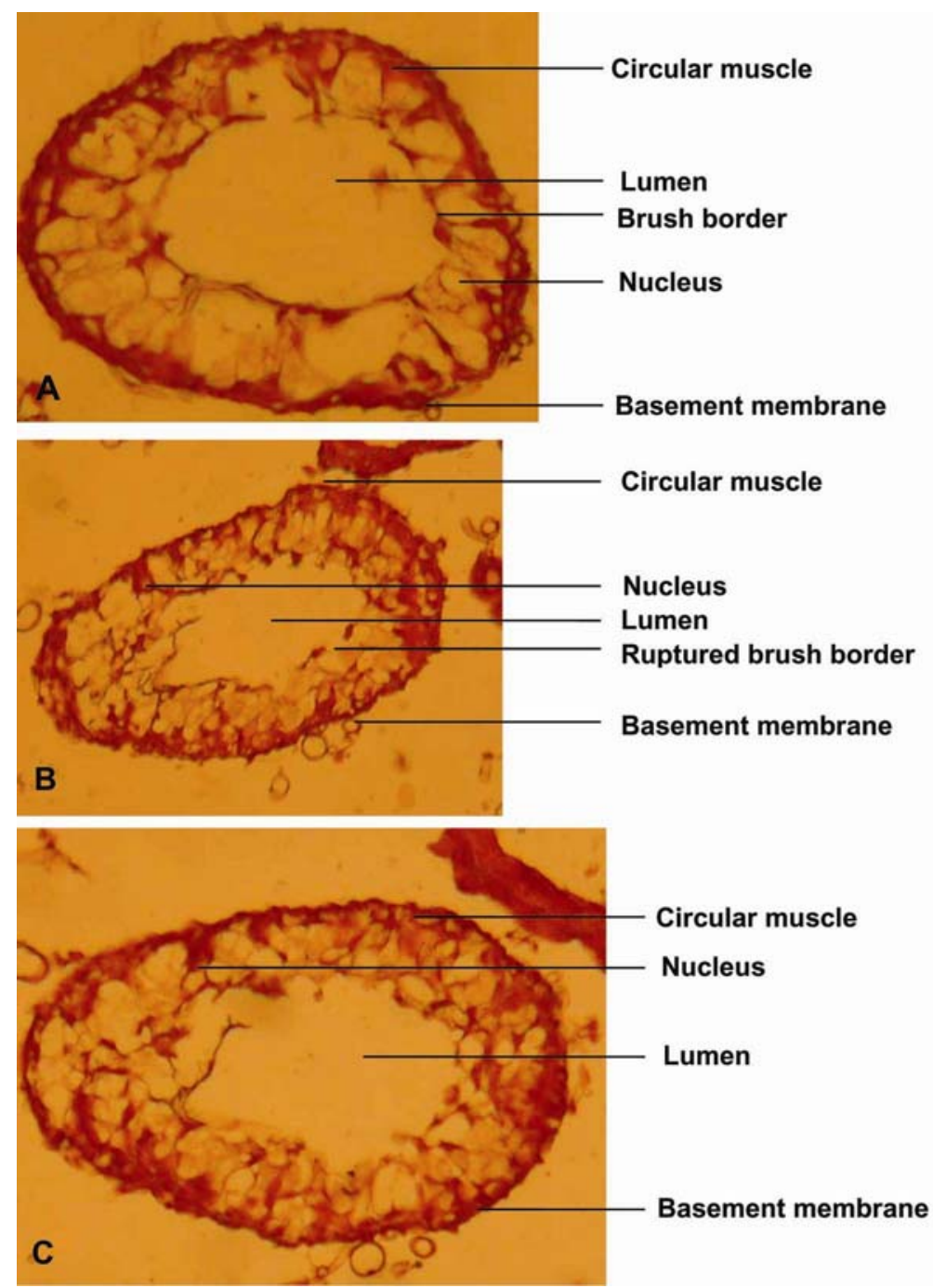

Fig. 2. Cross Section of Malpighian tubules of Lucilia cuprina showing constriction after treated with Monosodium glutamate (x40). A. Without treatment, B. Treatment with $5 \mathrm{~g}$ dose and C. $0.5 \mathrm{~g}$ dose.

with brain or by disrupting ionic balance. Most likely the target of MSG is to the $\mathrm{Na}^{+} / \mathrm{K}^{+}$channel of the excretory system. The ionic balance of the body was 
broken by MSG and ultimately the MTs were constricted and finally insects died. Generally, MSG is toxic to vertebrates and invertebrates. Mortality might occur for various reasons, either for the neurotoxicity or renal failure, or the factors yet to be identified. It was reported that higher doses of glutamate receptor resulted death of flesh fly, Neobelleiria bullata and desert locust, Schistocerca gregaria (Begum et al. 2004), which, however, is close to the present results.

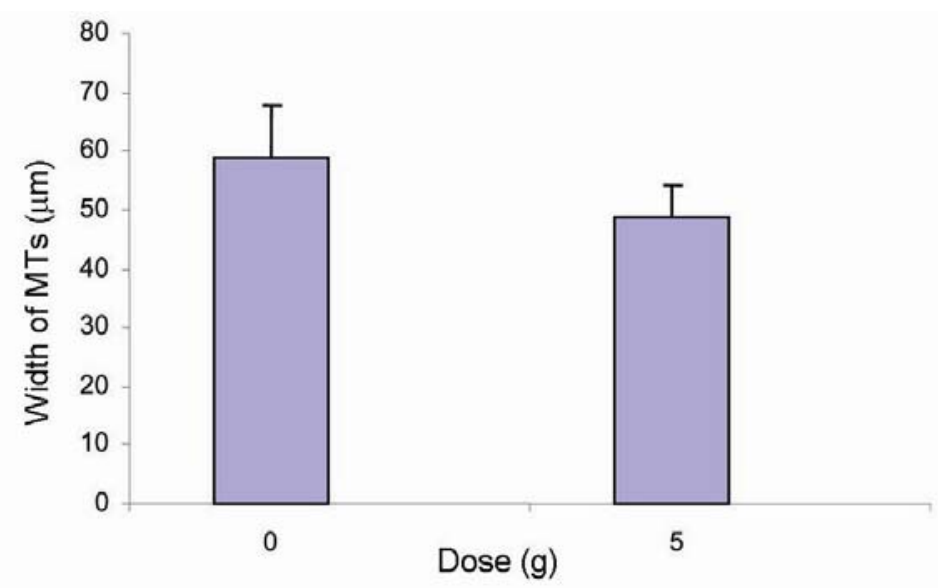

Fig. 3. Effect of MSG (5g) on the diameter (Mean \pm SD) of MTs of Lucilia cuprina.

The width of MTs was measured. Results indicated that MTs of L. cuprina became constricted after the administration of $5 \mathrm{~g}$ dose of MSG. In the histological studies, brush border was found to be ruptured. The ionic balance of the body in insect through "active transport" is maintained by the MTs. After ingestion of any toxic material, ionic balance of the body can be broken down (Lieberthat et al. 1998). Some of the former workers suggested that MSG somehow affects the renal system of vertebrates and invertebrates (Malpas et al. 1996, Lieberthat et al. 1998). In the histological slides the cross section of MTs in both treated and control (untreated) insects was observed. Constriction of MTs was found at $0.5 \mathrm{~g}$ and $5 \mathrm{~g}$ doses (Fig. $2 \mathrm{~B}, \mathrm{C}$ ), whereas no constriction was observed in control (Fig. 2A). In vertebrates, thet constriction of renal tissue occurred after administering different doses of MSG glutamate to rats (Ortiz et al. 2006). Apart from the renal system, other internal organs of vertebrates were also affected by MSG, for instance, histological changes were observed in the stomach (Eweka et al. 2007) and testes of adult rat (Eweka 2008). Reports indicated that glutamate was not only harmful for the renal system, but also harmful for other internal organs. 
Concluding remarks: Present study reveals the lethal effects of MSG on the histological changes of MTs in blowfly, L. cuprina. MSG has harmful affects on the histological changes of MTs of the fly. The tissue disruption of MTs was observed. Further research requires to know whether this drug has effects on other organs in insects.

\section{LITERATURE CITED}

ABBOTT, W.S. 1925. A method of computing the effectiveness of an insecticide. J. econ. Entomol. 18: $265-267$.

ANONYMOUS. 2003. Monosodium glutamate, a safety assessment. Technical report series no.20. Food standard Australia and New Zealand. $36 \mathrm{pp}$.

BEGUM, M., BREUER, M., KODRIK, D., RAHMAN, M.M. and LOOF, D.A. 2004. The NMDA receptor antagonist MK-801 inhibits vitellogenesis in the flesh fly Neobellieria bullata and in the desert locust Schistocerca gregaria. J. Insect Physiol. 50: 927-934.

CHAPMAN, R.F. 1982. The Insects Structure and Function. Cambridge University Press, Third edition. 916 pp.

CHOWDHURY, S.F.N. and RAHMAN, M.F. 2008 Anatomy and Histology of Malpighian tubules of Necrobia rufipes De Geer (Coleoptera: Cleridae). Bangladesh J. Zool. 36(1): 27- 34.

EWEKA, A.O. 2007. Histological studies on the effects of monosodium glutamate on the kidney of Adult Wistar Rats. J. Health. 6(2): 7-12.

EWEKA, A.O., OM'INIABOHS, F.A.E. and ADJENE, J.O. 2007. Histological studies on the effects of monosodium glutamate on the stomach of Adult Wistar Rats. Annal. Biomed. Sci. 6(1): 45 52.

EWEKA, A.O. 2008. Histological studies on the effects of monosodium glutamate on the testis of Adult Wister Rats. J. Urol. 5 (2): 41-45.

FLYNN, K. M., MILLER, S. A., SOWER, S. A. and SCHRIBMAN, M. P. 2002. Sexually dimorphic effects of NMDA receptor antagonism on brain-pituitary-gonad axis development in the platyfish. Comp. Biochem. Physiol. Part-C, 131: 9-18.

LIEBERTHAT, W., MENZA, S.A. and LEVINE, J.S. 1998. Graded ATP depletion can cause necrosis or apoptosis of cultured mouse proximal tubular cells. American J. Physiol .274: 315-327.

MALPAS, S.C., HEAD, G.A. and ANDERSON, W.P.1996. Renal responses to increases in renal sympathetic nerve activity induced by brainstem stimulation in rabbits. J. Auton. Nerv. Syst. 61(1): 70-78.

OM'INIABOHS, F.A.E. and EWEKA, A.O. 2007. Histological studies of the effects of monosodium glutamate on the Superior Colliculus of adult Wistar rats. The J. Neurol. 8(2): 21-25.

ORTIZ, G.G., BITZER-QUINTERO, O.K. and BEAS ZARATE, C. 2006. Monosodium glutamate induced damage in liver and kidney: a morphological and biochemical approach. J. Biomed. \& Pharmacotherapy 60(2): 86-91.

SCHAUMBURG, H.H., BYCK, R., GERSTL, R. and MASHMAN, J.H. 1969. Monosodium L glutamate:its pharmacology and role in the Chinese restaurant syndrome. Science 163: 826828. 